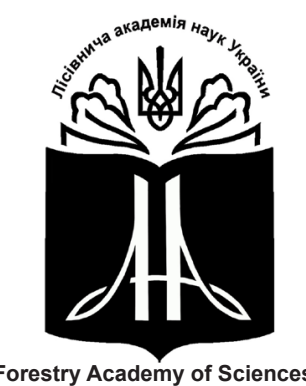

of Ukraine

Наукові праці Лісівничої академії наук України Proceedings of the Forestry Academy of Sciences of Ukraine

http://fasu.nltu.edu.ua https://doi.org/10.15421/411810

Article received 2018.02.08

Article accepted 2018.05.31
ISSN 1991-606X print

ISSN 2616-5015 online

(a) $\triangle$ Correspondence author

Vasyl Yukhnovskyi

yukhnov@ukr.net

General Rodimtsev str., 19, Kyiv, 03041, Ukraine

УДК 712.2(47+57)

\title{
Порівняльний аналіз класифікацій зелених насаджень населених пунктів України та пострадянських країн
}

\author{
В.Ю. Юхновський ${ }^{1}$ О.В. Зібцева ${ }^{2}$
}

Окреслено сучасні підходи до озеленення урбосередовища: концепції зеленого простору, зеленої інфраструктури та сталість поглядів в Україні, де збереглися традииії з радянських часів. Обтрунтовано доцільність структурування зелених насаджень з компонентами, які виокремлюють фізичний вигляд, просторову мозаїчність, соціальну функцію, доступність, екосистемні послуги, збереження біорізноманіття, антропогенний вплив, функціональне призначення. Охарактеризовано поняття зеленої інфраструктурної мережі як сукупності різних видів рослинності і відкритих просторів, інтегрованих у здоров'я та якість життя людей, щзо підтримують і посилюють природні та екологічні процеси. Проаналізовано трансформацію класифікації зелених насаджень населених пунктів України та інших пострадянських країн. Виявлено принципові відмінності у переліку класифікаційних груп насаджень та проаналізована їхню доцільність. Виявлено недоліки класифікації зелених насаджень, використовуваної в Украӥні: суперечливий розподіл за групами насаджень, не чітко прописані переліки груп, наявність у двох категоріях незрозумілих «інших» насаджень. Встановлено, які саме теоретичні аспекти та деталі функиіональної класифікації доцільно запозичити в інших пострадянських країнах. Розглянуто основні показники озеленення, коректність їх визначень, а також динаміка мінімальних розмірів зелених насаджень загального користування: парків, садів, скверів. Зазначено, щзо нормативне зниження у 5-7,5 раз мінімальної площзі парків і у 25 разів - мінімальної площзі скверів призводить до небажаної фрагментації зелених просторів. 3'ясовано, щзо показники озеленення потребують чіткішого визначення та сучасної аргументації щзодо їх нормативних кількісних значень. Підкреслено переваги класифікаиії зелених насаджень, використовуваної у Білорусії.

Ключові слова: зелений простір; зелені насадження; озеленення; норма озеленення; ступінь озеленення; парк; сад; сквер; антропогенний вплив; урбосередовище.

Вступ. Міський зелений простір - найважливіший вид використання міських земель, що підвищує життєздатність міст (Fung et al., 2008), впливає на їхнє середовище, робить міста привабливими не лише для своїх громадян, але й для відвідувачів та інвестицій (Arvanitidis et al., 2009), сприяє відновленню психологічної втоми, слугуючи ресурсом для фізичної активності, знижуючи смертність i рівень стресу (Schipperijn et al., 2010), відіграє важливу і позитивну роль у глобальному вуглецевому циклі, зменшенні ефекту міського теплового острова та зміни клімату, наданні екосистемних та естетичних послуг (Ramos-Gonzalez, 2014), сприянні гармонійному взаємозв’язку між людиною та природою (Wang et al., 2012). Природні території наповнюють життя людей натхненням та емоціями,

\footnotetext{
Юхновський Василь Юрійович - дійсний член Лісівничої академії наук України, доктор сільськогосподарських наук, професор кафедри відтворення лісів та лісових меліорацій. Національний університет біоресурсів і природокористування України, вул. генерала Родимцева, 19, м. Київ, 03041, Україна. Тел.: +38-067-720-32-16. E-mail: yukhnov@ukr.net

2 Зібцева Ольга Василівна - кандидат сільськогосподарських наук, доцент кафедри ландшафтної архітектури та садово-паркового будівництва. Національний університет біоресурсів і природокористування України, вул. генерала Родимцева, 19, м. Київ, 03041, Україна. Тел.: +38-050-835-77-74. E-mail: stplut2017@gmail.com
} 
мають вирішальне значення для функціонування сучасного міста та добробуту мешканців, є ключовими компонентами стійких урболандшафтів (Rostami et al., 2015).

Наразі в Україні не використовується ні концепція зеленого простору, ні зеленої інфраструктури, залишається невизначеною спроможність застосовуваної класифікації зелених насаджень слугувати сучасним урбаністичним ідеям.

Процес урбанізації призводить до зменшення природних і штучно озеленених територій на користь забудови, яка все більш переущільнюється, внаслідок чого зростають техногенні навантаження і забруднення міського середовища (Teodoronskiy et al., 2011). В основі ландшафтної організації території міста лежить створення єдиної системи озеленення, яка виконує середовище захисні і середовище формуючі функції.

Міська структура - просторово-динамічний, «живий організм», в якому система озеленених просторів розглядається не як обмежувач розвитку, а як каталізатор і стимулятор, здатний надати простору більш придатне для життя якісне середовище (Voronina, 2011). Побудова ефективної та гармонійної міської екологічної мережі та підтримка стійкого життєвого середовища у відповідь на швидку урбанізацію є ключовими питаннями, що потребують вирішення (Li et al., 2015).

Об'єкти та методика досліджень. Об ' $\epsilon$ 'к досліджень - система зелених насаджень населених пунктів України. Предмет досліджень - понятійнотермінологічний аспект систематики (типологіï) зелених насаджень населених пунктів України.

Мета роботи - оцінити прогресивність і досконалість сучасної функціональної класифікації зелених насаджень населених пунктів України на основі порівняння ii iз використовуваною раніше (у повоєнні 50-ті роки) та 3 використовуваними наразі в інших пострадянських країнах.

Типологія як метод дослідження широко використовується в різних галузях, а типологічна класифікація як метод та наукова дисципліна є міцним інструментом, що дає змогу систематизувати наявні знання, легше отримати інформацію, виокремити невідомі факти і з'єднати старі знання 3 новими в єдину систему (Younga et al., 2014). Причому, розвиватимуться типології, які використовуються як інструмент планування, а ті, що не мають специфічного, місцевого розуміння елементів, мають обмежену цінність. Структурування можуть включати фізичний вигляд, просторовий ступінь та складність, соціальну функцію, власність та доступ, кількість та якість наданих екосистемних послуг, роль у збереженні біорізноманіття, інтенсивність впливу людини, відповідне призначення у плануванні та просторовій стратегії (Braquinho et al., 2015).

Дослідження здійснено на основі аналізу нормативних і літературних джерел та порівнянні різних методів класифікації систем озеленення міст 3 використанням системного підходу. Розглядається українська класифікація у динаміці 3 радянських часів (взяті дані 50-х років минулого сторіччя і сучасні нормативи), іiї відмінність від сучасної класифікації, прийнятої у пострадянських країнах (Росії, Білорусіі, Молдові, Грузіі).

Результати та обговорення. У підході до озеленення урбосистем існує принципова відмінність між пострадянськими та європейськими й іншими країнами світу. В Україні, як і в колишньому Радянському Союзі та в сучасних пострадянських країнах, традиційно озеленені території здебільшого розглядають і понятійно регламентують як «зелені насадження», на відміну від країн Свропи, Америки та решти країн світу, де використовують поняття «зелені простори» (території), що виглядає більш системно і обгрунтовано.

Міський зелений простір - це всі рослинні покриви у містах та навколо них, включаючи міські ліси, пасовища, парки, сади, зелені дахи, міські ферми та вуличні дерева, які надають екосистемні послуги і відіграють важливу роль у пом'якшенні негативних наслідків, зумовлених урбанізацією (Yu et al., 2017).

На пострадянському просторі поняття зеленого простору застосовують, наприклад, у Литві, де за використанням «незалежні зелені простори» поділяють на рекреаційні; наукові, культурні і меморіальні; захисні та екологічні, а «залежні зелені простори» - на озеленення житлових, публічних, промислових, складських, комерційних територій; інженерної інфраструктури; рекреаційне озеленення (Brinkyte, 2013).

Найсучасніший погляд на міську систему озеленення - концепція зеленої інфраструктури. Зелена інфраструктурна мережа - це сукупність різних видів зелені і різних видів відкритих просторів, пов'язаних вулицями, водними шляхами і дренажами, що поєднують міські райони в усіх просторових масштабах (Mansor et al., 2012). Зелена інфраструктура є взаємозв'язаною мережею принципово поліфункціональних природних територій та інших зелених просторів, інтегрованих у здоров'я та якість життя людей, що підтримують і посилюють природні та екологічні процеси. У цьому напрямку існують кількісні стандарти, висуваються абсолютні мінімальні вимоги, мінімальні розміри. Впродовж останнього десятиліття зелена інфраструктура перетворилася 3 нової ідеї на визнану практику планування. Загальноприйняті терміни визначають взаємозв' язану мережеву концепцію та диференціюються за шкалою, за якою відбувається планування зеленої інфраструктури і яка може бути вдосконалена на всіх рівнях - від найбільшого i до найменшого ландшафту (Allen, 2012). Швидка урбанізація та пов'язана 3 нею розбудова сірої і зеленої інфраструктур забезпечила підгрунтя для капітального перегляду стандартів та моделей зеленого простору (Jim \& Chen, 2003).

O. Vodyanik (2017) виділяє 34 основні функції міських зелених насаджень, але базовою функцією системи міського озеленення вважає задоволення потреби містян у здоров’ї. За його даними, у 
1970-1990 рр. в СРСР була випущена велика кількість нормативних положень, які регламентували площі, типи і види функціонального озеленення, а 3 початку 1990-х міське озеленення перестали сприймати як інфраструктуру, що визначає здоров'я містян, натомість виникла уява про виключно естетичну складову.

За діючими в Україні нормативами зелені насадження населених пунктів класифікуєть за просторовою (міські і заміські) і функціональною ознаками (зелені насадження загального користування, обмеженого користування і спеціального призначення). Другий розділ документу «Правила утримання зелених насаджень у населених пунктах України» містить визначення термінів, відповідно до яких озеленення населених місць $є$ синонімом системи зелених насаджень населених пунктів, а класифікація за функціональною ознакою виглядає наступним чином (дослівно, виділимо суперечливі моменти, на яких зупинимося детальніше).

Зелені насадження загального користування насадження, які розташовані на території загальноміських і районних парків, спеціалізованих парків, парків культури та відпочинку; на територіях зоопарків та ботанічних садів, міських садів і садів житлових районів, міжквартальних або при групі житлових будинків; скверів, бульварів, насадження на схилах, набережних, лісопарків, лугопарків, гідропарків та інших, які мають вільний доступ для відпочинку.

Зелені насадження обмеженого користування насадження на територіях громадських і житлових будинків, шкіл, дитячих установ, вищих та середніх спеціальних навчальних закладів, профтехучилищ, закладів охорони здоров'я, промислових підприємств і складських зон, санаторіїв, культурноосвітніх і спортивно-оздоровчих установ та інші.

Зелені насадження спеціального призначення насадження транспортних магістралей і вулиць; на ділянках санітарно-захисних зон довкола промислових підприємств; виставок, кладовищ і крематоріїв, ліній електропередач високої напруги; лісомеліоративні, водоохоронні, вітрозахисні, протиерозійні, насадження розсадників, квітникарських господарств, пришляхові насадження в межах населених пунктів.

Кардинальна відмінність української класифікації від російської полягає в тому, що в Росії вуличні насадження віднесені до насаджень загального користування, а насадження зоопарків і ботанічних садів - навпаки, до насаджень спеціального призначення, в чому часто плутаються й українські вчені (Potapenko \& Kuznetsov, 2009). I, якщо в нашій українській класифікації віднесення вуличних насаджень до насаджень спеціального призначення здається цілком логічним, то що стосується зелених насаджень зоопарків і ботанічних садів, існуючий розподіл не видається достатньо переконливим. На нашу думку, доцільнішим було б віднесення цих об'єктів або до спеціального призначення (як таких, що виконують важливу спеціальну функцію), або хоча б до обмеженого користування (як зелені насадження на території наукових установ). До речі, в низці регламентуючих документів РФ чітко прописано, що до зелених насаджень загального користування відносять такі, що мають вільний доступ для необмеженого кола осіб, а до зелених насаджень обмеженого користування - зелені насадження на земельних ділянках, призначених для рекреаційних цілей, доступ до яких здійснюється на платній основі або обмежений особливим режимом використання (Smirnov, 2009), що цілком підходить до території наших ботанічних садів і зоопарків.

Варто зазначити, що ще у 50-х роках XX ст. вважалося неправильним віднесення ботанічних $\mathrm{i}$ зоологічних садів і спортивних майданчиків до однієї категорії із садами і скверами (Lypa et al., 1952; The handbook of architect, 1946). Натомість вважалося правильним віднесення ботанічних і зоологічних садів до насаджень спеціального призначення, а спортивних майданчиків - до фізкультурних споруд.

Ще логічнішим виглядає розподіл зелених насаджень у сучасній класифікації Білорусі, де зелені насадження поділені не на три, а на п’ять категорій i за вуличними насадженнями закріплена окрема ніша (група насаджень), що, вважаємо, цілком обгрунтовується іiї особливим місцем, значимістю як у планувальній структурі міста, та і виконуваного нею на території населених пунктів комплексу функцій, насамперед санітарно-гігієнічних та естетичних (Order of the Ministry of Natural Resources and Environmental Protection of the Belarus Republic, 1998).

Віднесення в сучасній українські класифікації до категорії зелених насаджень загального користування «міжквартальних садів або при групі житлових будинків» також $є$ відмінністю від класифікації повоєнної, за якої виділялася категорія, що мала загальну назву «внутрішньо квартальні зелені насадження або насадження обмеженого користування», до якої належали присадибні сади і палісадники.

Не достатньо логічним виглядає віднесення до насаджень загального користування насаджень на схилах. У будь-яких складних умовах профілюючою $є$ екологічна (природозахисна) функція зелених насаджень, тому їх місце, на нашу думку, серед протиерозійних насаджень, тобто в категорії насаджень спеціального призначення, як це зафіксовано у законодавстві, наприклад, Грузії (Gedevanishvili, 2006).

Наявність у переліку двох функціональних груп «інших» зелених насаджень зумовлює суперечності й непорозуміння, зокрема, у щорічній статистичній звітності про зелене господарство України, до якої виникає багато запитань (Zibtseva, 2017).

На жаль, ніде в українській класифікації не згадується категорія «міські ліси», які у повоєнні роки входили до категорії зелених насаджень загального користування i навіть передбачався окремий норматив, яку площу вони мали складати на душу населення. 3 огляду на наукові джерела, у багатьох країнах світу поняття «міський ліс» стосується будь-якої деревної рослинності на міській тери- 
торії. Наприклад, у законодавстві Молдови чітко прописано, що до зелених насаджень населених пунктів не відноситься рослинність лісового фонду. Натомість, для Грузії характерне віднесення лісів до групи зелених насаджень спеціального призначення (Gedevanishvili, 2006), а в законодавстві Білорусі (Order of the Ministry of Natural Resources and Environmental Protection of the Belarus Republic, 1998) «невпорядковані лісові масиви» в межах населених пунктів належать до групи «інших об’єктів рослинного світу», яку можна розглядати як тимчасову, тому що у класифікації зазначається, що на iii базі створюють насадження однієї із решти груп насаджень (загального користування, обмеженого користування, спеціального призначення, на вулицях населених пунктів). Цінність цієї класифікації полягає в тому, що тут чітко прописано положення про неможливість забудови на місці лісових масивів у межах населених пунктів, що, внаслідок неякісності українського законодавства, відбувається повсюдно. Небезпека ж законодавчої класифікації республіки Молдова полягає в тому, що, якщо галузь або ресурс не керуються 3 одного органу, вони перестають бути системою. Про це забувають і в Україні, де озелененням опікується житловокомунальне господарство.

Навіть для території м. Києва, де наразі районні адміністрації відсутні, згадка у визначенні зелених насаджень загального користування «на теритоpiї загальноміських і районних парків» є зайвою. Більш вдалим, порівняно 3 українським, виглядає термінологічне визначення насаджень загального користування у Білорусі. Замість довгого і не зовсім зрозумілого переліку садів і парків з вказівкою класифікації, приналежності або підпорядкування, чітко прописано: містить «багатофункціональні і спеціалізовані парки». У білоруській класифікації немає понятійної різниці між парками і садами, сади (як місця рекреації) не згадуються. Хотілося б запозичити з переліку зелених насаджень Білорусі до нашої класифікації «зони короткочасної рекреації біля води, озеленені ділянки суспільних центрів загальноміського і районного рівнів, призначені для організації різних форм масового відпочинку населення», i тим самим позбутися непевних «інших» насаджень у нашому переліку. Один із основних недоліків будь-якої типології - непевність і неточність, якої необхідно позбуватися.

Коректніше виглядає й білоруський понятійнотермінологічний перелік зелених насаджень обмеженого користування, де чітко вказана функція цієї групи насаджень (для повсякденного відпочинку населення), окреслюється територіальний характер, встановлено види забудови, вказано для кого вони призначені (для обмеженого контингенту відвідувачів), що дає змогу виключити з переліку «інші» насадження. Мабуть, в ідеалі доцільно було б запозичити у білорусів визначення і цієї групи насаджень.

Віднесення в нашій класифікації зелених насаджень промислових підприємств і складських зон до насаджень обмеженого користування є логічним 3 погляду підвищення добробуту обмеженого контингенту працюючих на цих підприємствах. Але 3 погляду специфічних шкідливих умов таких територій і важливості санітарно-гігієнічних функцій зелених насаджень на даних територіях, доцільно віднести цю групу об'єктів до зелених насаджень спеціального призначення, як це й було в повоєнні роки - «на ділянках промислових підприємств всередині селітебної території» та «на території промислових підприємств, нафтобаз і складів» на заміських (позаселітебних) територіях.

Варто зазначити, що зелені насадження культурно-освітніх і спортивно-оздоровчих установ, які наразі належать до зелених насаджень обмеженого користування, у повоєнні 50-ті роки відносили до зелених насаджень спеціального призначення у вигляді насаджень стадіонів та іподромів. Детальний перелік насаджень цієї категорії дав би змогу позбутися сумнівної трактовки «інших» насаджень.

Вважаємо доцільним прописати у переліку зелених насаджень спеціального призначення категорію «зелені насадження протипожежних зон», як це зроблено, наприклад, для території СанктПетербургу (Smirnov, 2009), де необхідність такої дії продиктована сучасним станом речей і навіть змінами клімату. Доцільно додати до цієї групи насаджень зазначене в сусідніх державах у цій же групі насаджень «озеленення дахів житлових і промислових будівель».

Порівняно $з$ повоєнними роками, зникла окрема категорія «насадження захисного значення (у середині контуру селітебної території)». На жаль, наразі в українській класифікації не згадується приналежність дендрологічних парків і заповідників, які у повоєнні роки було віднесено до зелених насаджень спеціального призначення. Крім того, у 50-ті роки до зелених насаджень спеціального призначення належали насадження стадіонів, іподромів, а також на ділянках промислових підприємств всередині селітебної території, які тепер належать до насаджень обмеженого користування. У білоруській класифікації до цієї групи належать також насадження прибережних і берегоукріплювальних смуг та інші, призначені для виконання інженерно-технічних, санітарно-гігієнічних, науково-дослідних та інших функцій, - тобто для цієї групи насаджень характерна не рекреаційна, а інші функції.

Подібно до сучасної білоруської класифікації, у 50-ті роки виділяли окрему групу - вуличні лінійні насадження на селітебній території і насадження вздовж приміських доріг на позаселітебній (приміській) території (Lypa, 1952).

До «інших об'єктів рослинного світу», крім згадуваних невпорядкованих лісових масивів, у білоруській класифікації віднесено насадження, які збереглися після знесення індивідуальної забудови, рекультивовані звалища, полігони та кар'єри, насадження в зонах ліній електропередач, інженерних мереж комунікацій, плодові сади, що втратили своє 
виробниче значення, тимчасово озеленені території (Yerilin, 2014).

У Республіці Молдова також застосовується поняття зелених насаджень, які $є$ архітектурно гармонізованими системами, утвореними 3 елементів ландшафтного комплексу в межах міста і сільських населених пунктів (природні ландшафти в межах міста, ділянки водотоків і водойм, дорожні, садові і житлові споруди) (Law of the Moldova Republic, 1999). На наш погляд, визначення не достатньо повне і логічне. Але, надважливою деталлю закону $є$ те, що в ньому прописана функція зелених насаджень - збереження водних ресурсів, що необхідно зробити і в законодавчих актах України. Не включається до зелених насаджень населених пунктів рослинність, яка входить до лісового фонду, захисні зони і смуги річок і водойм, лісозахисні смуги, деревно-кущові насадження вздовж шляхів сполучення, фонд природних територій, що охороняються державою, лісозахисні зони гідрометеорологічних станцій і постів, а також водозаборів (Gedevanishvili, 2006).

Для Грузії характерна спроба перейти від зелених насаджень до озеленених територій. Відповідно до прийнятої у Грузії класифікації, озеленені території поділяються за призначенням на три аналогічні колишній радянській класифікації категорії суспільні (загального користування), обмеженого користування і спеціального призначення. До суспільних озеленених територій належать найбільші планувальні елементи системи (парки, сади, сквери, бульвари, лісопарки та ін.), використовувані 3 метою рекреації. До озеленених територій обмеженого користування - двори промислових, навчальних, наукових, культурних, медичних установ та інші режимні території, спортивні споруди обмеженого користування. До категорії зелених насаджень спеціального призначення належить озеленення вулиць і площ, ліси, схили, розсадники, кладовища, зони санітарної охорони. Загалом, поелементно тут немає розбіжностей із українською класифікацією.

За викладеними в «Правилах утримання...» (Rules for the maintenance of green plantations in settlements of Ukraine, 2006) термінологічними нормативами, парк - це самостійний архітектурноорганізаційний комплекс площею понад 2 га, який виконує санітарно-гігієнічні функції та призначений для короткочасного відпочинку населення. Сади - упорядковані масиви зелених насаджень площею від 2 до 6 га, призначені для короткочасного відпочинку населення. Сквер - упорядкована й озеленена ділянка площею від 0,02 до 2,0 га, яка $\epsilon$ елементом архітектурно-художнього оформлення населених місць, призначена для короткочасного відпочинку населення.

Потрібно зазначити, що за нормативами Діпроміста УРСР (РДМУ 204 УССР 041-84) було рекомендовано значно більші площі зазначених об’єктів. Так, розміри міських парків змінювалися в межах 10-15 га, міських садів - від 5 до 10 га, скверів - від 0,5 до 3,0 га. Водночас, на практиці допускалося відхилення від нормативів: сквери мали площу від 0,1-0,2 і до 4-5 га.

Таким чином, сучасна нормативна мінімальна площа парку знизилася порівняно 3 повоєнними роками (1947 р.) у 5-7,5 разів, що свідчить про фрагментацію зелених насаджень, яка не підтримується світовим науковим співтовариством, тому що це призводить до зниження якості системи зелених просторів. Категорія «сади» житлових кварталів останнім часом взагалі зникає з нормативного переліку, що на практиці одразу ж спонукає до ущільненого будівництва на їх територіях. Зменшення мінімальної площі скверів у 25 разів $(30,5$ до 0,02$)$ залишило шпаринку, за якою дрібні озеленені ділянки вуличного озеленення (нинішня категорія зелених насаджень спеціального призначення) «перетягуються» до категорії зелених насаджень загального користування, що дає змогу покращити показник забезпеченості зеленими насадженнями загального користування, наблизивши його до задекларованої у ДБН 360-92 норми озеленення.

За останніми радянськими нормативами розмір парків складав не менше 6 га. Розмір районного саду в Грузії наразі повинен складати не менше 4, мікрорайонного - не менше 1 га. Розмір скверів змінюється від 0,2 до 2-3 га. Парки у Молдові - зелені насадження площею понад 20 га, сади - від 3 до 20 га, сквери - до 3 га. У Білорусії загальноміські парки (сади) мають площу від 5 до 50 га (у великих містах - 100 га і більше), сквери - від 0,15 до 3 га, а парки (сади) районів житлової і змішаної забудови - до 5 га (табл. 1).

Великі за площею зелені масиви ще в 50-ті роки минулого сторіччя вважалися бажанішими 3 естетичних та екологічних міркувань (Lypa et al., 1952). Зменшення розміру зелених площ на рівні ландшафту означає фрагментацію міського зеленого простору, яка знижує його якість (Gupta et al., 2012). 3 цього погляду нормативи щодо мінімальних розмірів зелених насаджень загального користування в Україні виглядають найгірше.

Таблиия 1

Нормативні розміри парків, садів і скверів у різних країнах, га

\begin{tabular}{lcccccc}
\hline \multirow{2}{*}{ Об'єкт } & \multicolumn{2}{c}{ Україна } & \multirow{2}{*}{ Білорусія } & Грузія & Молдова & \multirow{2}{*}{ Росія } \\
\cline { 2 - 4 } & на 01.01 .2006 & на 01.01 .1952 & & & \\
\hline Парк & $\geq 2$ & $10-15$ & $5-50(100)$ & $\geq 6$ & $>20$ & $\geq 6$ \\
Сад & $2-6$ & $5-10$ & $\leq 5$ & $\geq 4$ & $3-20$ & $\geq 4$ \\
Сквер & $0,02-2$ & $0,5-3$ & $0,15-3$ & $0,2-3$ & $\leq 3$ & не нормується \\
\hline
\end{tabular}


Норма озеленення - площа озеленених територій загального користування, яка припадає на одного жителя (Rules for the maintenance of green plantations..., 2006). Варто зазначити, що саме таке визначення $\epsilon$ тлумаченням терміну «забезпеченість зеленими насадженнями загального користування», яке характеризує існуючу ситуацію у населеному пункті, а при визначенні норми озеленення доцільно додати, що відповідно до вимог Державних будівельних норм, це «мінімальна нормативна площа».

Ступінь озеленення - відношення площі озеленених територій до загальної площі міста, одиниці його адміністративного поділу або окремої функціональної території, розрахована у відсотках (Rules..., 2006). На жаль, навіть у різних нормативних документах $\epsilon$ різні інтерпретації і розбіжності. Так, у ДБН України («Містобудування. Склад і зміст плану зонування території») термін «ступінь (або рівень) озеленення» підміняється терміном «коефіцієнт озеленення», що вносить непотрібну плутанину. Те ж саме спостерігається і в аналогічних документах Російської Федерації. Коефіцієнт, зазвичай, величина безрозмірна, тому його вираження у відсотках виглядає не коректно.

У повоєнні роки норми площі зелених насаджень на одного жителя (на душу населення), зокрема норма зелених насаджень загального користування (душова норма) порівнювалися з нормативами, які не можна було вважати встановленими, оскільки ще не було загальноприйнятої номенклатури зелених насаджень загального користування (Lypa et al., 1952).

До 1930-1931 рр. було рекомендовано норму зелених насаджень для нових міст від 20,5 до 36,0 м $^{2}$ на жителя, у т.ч. лісу - 12-20 м²/чол. (табл. 2).

Таблиия 2

Динаміка норми озеленення на території населених пунктів України

\begin{tabular}{|c|c|c|}
\hline $\begin{array}{l}\text { Період, } \\
\text { рік }\end{array}$ & $\begin{array}{c}\text { Норма озеленення, } \\
\text { м²/люд. }\end{array}$ & Примітки \\
\hline До 1930-1931 & $20,5-36$ & у т.ч. лісу $12-20 \mathrm{~m}^{2}$ \\
\hline 1934 & 30 & \\
\hline 1940 & $15-21$ & мінімальна \\
\hline 1944 & $15-20$ & мінімальна \\
\hline 1952 & $25-26$ & $\begin{array}{c}\text { у т.ч. парків } \\
18-19 \text { м }^{2}\end{array}$ \\
\hline 1984 & $16-20$ & \\
\hline 1992 & $6-17$ & \\
\hline
\end{tabular}

У 1934 р. було запропоновано норму зелених насаджень загального користування у розмірі $30 \mathrm{~m}^{2}$ на жителя, а в 1940 р. академія комунального господарства рекомендувала норму в 15-21 м²/люд. У 1944 р. академія архітектури СРСР запропонувала диференціювати душову норму зелених насаджень залежно від площі населеного пункту 15-20 м²/люд. На думку авторів (Lypa et al., 1952), такі норми потрібно розглядати як мінімальні. У проектно-планувальній практиці Діпроміста УРСР застосовували диференційовані душові норми зелених насаджень загального користування (The regulations of designing of cities and settlements of urban type, 1947), які автори вважали оптимальними і за якими норма зелених насаджень у містах 3 населенням 10-50 тис. мешканців складала 25-26 м²/люд., у тому числі норма паркових насаджень становила 18-19 м²/люд.

Норма внутрішньоквартальних зелених насаджень (насадження обмеженого користування) була встановлена керівництвом УРСР ще у 1931 р. в розмірі $10 \mathrm{~m}^{2} /$ чол., а на практиці збільшувалася до 15-20 м²/ люд. і більше. ІІї величина була обернено пропорційна поверхні забудови.

Дані табл. 2 свідчать, що в Україні існує тенденція до скорочення норми озеленення, причому за період майже у сто років - більше, ніж удвічі, що наразі суперечить загальноприйнятому курсу на створення стабільного екологозбалансованого урбосередовища.

Висновки. Класифікація зелених насаджень, яку використовують в Україні, має низку недоліків: суперечливий розподіл за групами насаджень; не послідовно викладено переліки груп, не чітко прописані їхні визначення; наявність у категоріях загального і обмеженого користування незрозумілих термінів - «інших» насаджень.

У нормативах щодо зелених насаджень загального користування простежується зниження їх величин, тобто узаконена фрагментація зелених просторів. Самі показники озеленення потребують більш чіткого визначення, а також сучасної аргументації щодо їх нормативних кількісних значень.

Порівняльним аналізом встановлено, що класифікація зелених насаджень Білорусі $є$ досконалішою на відміну від інших пострадянських країн.

\section{Бібліографічні посилання}

Allen, W. L. (2012). Environmental reviews and case studies: Advancing Green Infrastructure at All Scales: From Landscape to Site. Environmental practice, 14 (1), 17-25. https://doi.org/10.1017/ S1466046611000469

Arvanitidis, P. A., Lalenis, K., Petrakos, G., \& Psycharis, Ya. (2009). Economic aspects of urban green space: a survey of perceptions and attitudes. International Journal of Environmental Technology and Management, 11 (1/2/3), 143-168. https://doi. org/10.1504/IJETM.2009.027192

Braquinho, C., Cvejić, R., Eler, K., Gonzales, P., Haase, D., Hansen, R., Kabisch, N., Rall, E. L., Niemela, J., Pauleit, S., Pintar, M., Lafortezza, R., Santos, A., Strohbach, M., Vierikko, K., Železnikar, Š. (2015). A typology of urban green spaces, ecosystem provisioning services and demands. Report: D3.1 Retrieved from https://greensurge.eu/working-packages/wp3/files/D3.1_Typology_of_urban_green 
spaces_1_.pdf/D3.1_Typology_of_urban_green spaces_v2_.pdf

Brinkyte, E. (2013). Urban green space system: a case study of Siauliai city, 241-245. Retrieved from http:// www.su.lt/bylos/mokslo_leidiniai/jmd/10_01_26 priedas/brinkyte.pdf

Fung, T., So, L. L. H., Chen, Y., Shi, P., \& Wang, J. (2008). Analysis of green space in Chongqing and Nanjing, cities of China with ASTER images using object-oriented image classification and landscape metric analysis. International Journal of remote sensing, 29 (24), 7159-7180. https://doi. org/10.1080/01431160802199868

Gedevanishvili, M. (2006). Classification of greening areas, state of green space system in Tbilisi and resources of its development. Retrieved from https:// ge.boell.org/en/2006/09/24/sostoyanie-sistemyzelenyh-territoriy-g-tbilisi-i-vozmozhnosti-ee-razvitiya (in Russian).

Gupta, K., Kumar, P., Pathan, S. K., \& Sharma, K.P. (2012). Urban Neighborhood Green Index - A measure of green spaces in urban areas. Landscape and Urban Planning, 105 (3), 325-335. https://doi. org/10.1016/j.landurbplan

Jim, C. Y., \& Chen, S. S. (2003). Comprehensive green space planning based on landscape ecology principles in compact Nanjing city, China. Landscape and Urban Planning, 65 (3), 95-116. https://doi. org/10.1016/S0169-2046(02)00244-X

Law of the Moldova Republic from 23.09.1999 N 591. About green plantings of urban and rural settlements. Retrieved from http://lex.justice.md/viewdoc.php ?action $=$ view \&view $=$ doc\&id $=311847 \&$ lang $=1 \quad$ (in Russian).

Li, H., Chen, W., \& He, W. (2015). Planning of Green Space Ecological Network in Urban Areas: An Example of Nanchang, China. International Journal of Environmental Research and Public Health, 12 (10), 12889-12904. https://doi.org/10.3390/ ijerph121012889

Lypa, A. L., Kosarevskiy, I. A., \& Salatich, A. K. (1952). Greening of settlements. Kiev, Publ. Academy of Sciences Ukrainian SSR, 743 (in Russian).

Mansor, M., Said, I., Mohamad, I. (2012). Experiential contacts with green infrastructure's diversity and well-being of urban community. Procedia - Social and Behavioral Sciences, 49, 257-267. https://doi. org/10.1016/j.sbspro.2012.07.024

Order of the Ministry of Natural Resources and Environmental Protection of the Belarus Republic from December 29, 1998 N 400 On Approval of Documents. Retrieved from http://pravo.levonevsky. org/search.htm (in Russian).

Potapenko I. L., \& Kuznetsov, S. I. (2009). Arboreal plants in the populated areas of the Eastern region of the Crimean. Plant introduction, 1, 63-67 (in Russian).

Ramos Gonzalez, O. M. (2014). The green areas of San Juan, Puerto Rico. Ecology and society, 19, 3. http:// dx.doi.org/10.5751/ES-06598-190321
Rostami, R., Lamit, H., Khoshnava, S. M., Fitry, M.S. Rosley, G. (2015). Sustainable Cities and the Contribution of Historical Urban Green Spaces: A Case Study of Historical Persian Gardens. Sustainability, 7 (10), 13290-13316. https://doi. org/10.3390/su71013290

Rules for the maintenance of green plantations in settlements of Ukraine. (2006). Kyiv, Ukraine. Retrieved from http://zakon.rada.gov.ua/go/z088006 (in Ukrainian).

Schipperijn, J., Stigsdotter, U. K., Randrup, T. B., Troelsen, J. (2010). Influences on the use of urban green space - A case study in Odense, Denmark. Urban Forestry \& Urban Greening, 9, (1), 25-32. https://doi.org/10.1016/j.ufug.2009.09.002

Smirnov, A. N. (2009). Problems of green areas surveying. Retrieved from http://gugenplan.spb. ru/UserFiles/File/tezisy_4-6_03_09/mejevanie_ smirnov.doc (in Russian).

Teodoronskiy, V. S., Gorbatova, B. I., \& Gorbatov, V. I. (2011). Greening of settlements with basics of urbanities. Moscow, Academy (in Russian).

The handbook of architect (1946). Moscow, USSR (in Russian).

The regulations of designing cities and urban type settlements. (1947). Kiev, USSR, 2 (in Russian).

Vodyanik, A. (2017). Greening of cities - construction, which by irregular assembly can result to negative effect. Green portal. Retrieved from http:// greenbelarus.info/articles/27-01-2017/ozeleneniegorodov-konstrukciya-kotoraya-pri-nepravilnoysborke-mozhet-privesti (in Russian).

Voronina, A. V. (2011). The landscape approach in urbanistic studies of European cities at the beginning of XXI century. Works of masters and graduate students. Architecture, Ecology. Nizhegorodskiy SABI, N. Novgorod, Russia, 35-40 (in Russian).

Wang, X. S.; Chen, E. X., Li, Z. Y., Yao, W. Q., \& Wang, L. (2012). Study on Urban Green Space Extracting and Dynamic Monitoring Method. 1st International Conference on Agro-Geoinformatics, Shanghai, China, 14-17. https://doi.org/10.1109/ Agro-Geoinformatics.2012.6311601

Yerilin, G. I. (2014). Accounting for flora objects on the lands of settlements. Center for Economic Projects, Ecology in the enterprise. Retrieved from http://www.ecolog.by/articles/rastitelnyy-mir/2051uchet-obektov-rastitelnogo-mira-pravovaya-osnova/ (in Russian).

Younga, R., Zandersb, J., Fassman-Beckc, E. (2014). A comprehensive typology for mainstreaming urban green infrastructure. Journal of Hydrology, 519 (27), 2571-2583. https://doi.org/10.1016/j. jhydrol.2014.05.048

Yu, Z., Wang, Y., Deng, J., Shen, Z., Wang, K., Zhu, J., \& Gan, M.. (2017). Dynamics of Hierarchical Urban Green Space Patches and Implications for Management Policy. Sensors, 17(6), 1304. https:// doi.org/10.3390/s17061304 
Zibtseva, O. V. (2017). Dynamics of green spaces in the settlements of Ukraine. Scientific reports of NULES of Ukraine, 4 (68). Retrieved from http://journals. nubip.edu.ua/index.php/Dopovidi/article/view/9123 (in Ukrainian).

\section{Сравнительный анализ классификаций зеленых насаждений населенных пунктов Украины и постсоветских стран}

\section{В. Ю. Юхновский ${ }^{\prime}$ О. В. Зибцева ${ }^{2}$}

Цель работы - оценить прогрессивность и совершенство современной функциональной классификации зеленых насаждений населенных пунктов Украины путем ее сравнения с используемой ранее (в 50-е годы прошлого столетия) и с классификациями, используемыми в настоящее время в других постсоветских странах (России, Белоруссии, Молдове, Грузии). Исследование проведено на основе сравнительного анализа нормативных и литературных источников, касающихся классификации зеленых насаждений, отдельных терминов и нормативов. Определены современные подходы к озеленению урбосреды: концепции зеленого пространства, зеленой инфраструктуры и постоянство взглядов в Украине, где сохранились традиции с советских времен. Обоснована целесообразность структурирования зеленых насаждений с компонентами, которые выделяют физический облик, пространственную мозаичность, социальную функцию, доступность, экосистемные услуги, сохранение биоразнообразия, антропогенное воздействие, функциональное назначение. Охарактеризованы понятия зеленой инфраструктурной сети как совокупности различных видов растительности и открытых пространств, интегрированных в здоровье и качество жизни людей, поддерживающих и усиливающих природные и экологические процессы. Проанализирована трансформация классификации зеленых насаждений населенных пунктов Украины и других постсоветских стран. Обнаружены принципиальные различия в перечне классификационных групп насаждений и проанализирована их целесообразность. Выявлены недостатки классификации

Юхновский Василий Юрьевич - академик Лесной академии наук Украины, доктор сельскохозяйственных наук, профессор кафедры возобновления лесов и лесных мелиораций. Национальный университет биоресурсов и природопользования Украины, ул. генерала Родимцева, 19, г. Киев, 03041, Украина. Тел.: +38-067-720-32-16. E-mail: yukhnov@ukr.net

Зибиева Ольга Васильевна - кандидат сельскохозяйственных наук, доцент кафедры ландшафтной архитектуры и садовопаркового строительства. Национальный университет биоресурсов и природопользования Украины, ул. генерала Родимцева, 19, г. Киев, 03041, Украина. Тел.: +38-050-835-77-74. E-mail: stplut2017@gmail.com зеленых насаждений, используемой в Украине: противоречивое распределение по группам насаждений, нечетко прописанные перечни групп, наличие в двух категориях неопределенных «других» насаждений. Установлено, какие теоретические аспекты и детали функциональной классификации целесообразно позаимствовать в классификациях других постсоветских стран. Рассмотрены основные показатели озеленения, корректность их определений, а также динамика минимальных размеров зеленых насаждений общего пользования: парков, садов, скверов. Отмечено, что нормативное снижение в 5-7,5 раза минимальной площади парков и в 25 раз - минимальной площади скверов приводит к нежелательной фрагментации зеленых пространств. Используемые основные показатели озеленения требуют четкого определения и современной аргументации относительно их нормативных количественных значений, на что планируется обратить внимание в дальнейшей работе. Подчеркнуты преимущества классификации зеленых насаждений, используемой в Белоруссии.

Ключевые слова: зеленое пространство; зеленые насаждения; озеленение; норма озеленения; степень озеленения; парк; сад; сквер; антропогенное воздействие; урбосреда.

\section{Comparative analysis of settlements green plantations classification in Ukraine and post-Soviet countries}

\section{Yukhnovskyi', O. Zibtseva²}

The aim of the paper is to assess the progressiveness and perfection of the modern functional classification of green spaces in settlements of Ukraine by comparing it with the one used earlier (in the 1950s) and the classifications currently used in other post-Soviet countries (Russia, Belarus, Moldova, Georgia). The study was conducted on the basis of a comparative analysis of normative and literature sources concerning the classification of green plantations, individual terms and standards. Modern approaches to greening the urban environment are outlined: the concept of green space, green infrastructure and the persistence of views in Ukraine, where traditions from the Soviet

Vasyl Yukhnovskyi - a full member of the Forest Academy of Sciences of Ukraine, Doctor of Agricultural Sciences, Professor of the department of forests restoration and forest meliorations. National University of Life and Environmental Sciences of Ukraine, st. General Rodimtsev, 19, Kyiv, 03041, Ukraine. Tel. + 38-067-720-3216. E-mail:yukhnov@ukr.net

Olga Zibtseva - Candidate of Agricultural Sciences, Assistant professor of the department of landscape architecture and gardening. National University of Life and Environmental Sciences of Ukraine, st. General Rodimtsev, 19, Kyiv, 03041, Ukraine. Tel: +38-050-835-77-74. E-mail: stplut2017@gmail.com 
era have survived. The expediency of structuring green plantations with components that distinguish physical appearance, spatial mosaic, social function, accessibility, ecosystem services, biodiversity conservation, anthropogenic influence, functional purpose is substantiated. The notion of a green infrastructurenetwork as a combination of differenttypes of vegetation and open spaces, integrated into health and quality of life of people that support and enhance natural and ecological processes is characterized. The transformation of the classification of green spaces of settlements of Ukraine and other post-Soviet countries has been analyzed. The principal differences in the list of classification groups of plantations are revealed and their expediency are analyzed. The shortcomings of the classification of green plantations used in Ukraine were identified: controversial distribution by planting groups, not clearly defined lists of groups, the presence of two unclear "other" plantations in two categories.
It is established which theoretical aspects and details of the functional classification should be borrowed in other post-Soviet countries. The main indicators of landscaping, the correctness of their definitions, as well as the dynamics of the minimum size of green spaces of general use: parks, gardens, squares, are considered. It is noted that the regulatory decrease of 5-7.5 times the minimum park area and 25 times - the minimum area of squares leads to undesirable fragmentation of green spaces. It has been determined that the indicators of landscaping require a clearer definition and modern arguments regarding their normative quantitative values, which is planned to pay attention in the future work. The advantages of the classification of green plantations used in Belarus are emphasized.

Key words: green space; green plantations; greening; norm of greenery; degree of landscaping; park; garden; square; anthropogenic impact; urban environment. 